\title{
LINKAGE OF AUTOSOMAL DOMINANT HEARING LOSS TO THE SHORT ARM OF CHROMOSOME 1 IN TWO FAMILIES
}

\author{
Paul Coucke, Guy Van Camp, Ph.D., Bulantrisna Djoyodiharjo, M.D., Shelley D. Smith, Ph.D., \\ Rune R. Frants, Ph.D., Georges W. Padberg, M.D., John K. Darby, M.D., Egbert H. Huizing, M.D., \\ Cor W.R.J. Cremers, M.D., William J. Kimberling, Ph.D., Ben A. Oostra, Ph.D., \\ Paul H. Van de Heyning, M.D., and Patrick J. Willems, M.D.
}

\begin{abstract}
Background. At least half of the cases of profound deafness of early onset are caused by genetic factors, but few of the genetic defects have been identified. This is particularly true of the most common hereditary forms of deafness, which occur in the absence of any associated syndrome.

Methods. We studied a large Indonesian family in which hearing loss was inherited in an autosomal dominant pattern. The hearing loss first affects the high frequencies during the teens or 20s and becomes profound within 10 years. To locate the responsible gene, we performed genetic-linkage analysis, using microsatellite markers distributed over the entire genome. We then performed linkage analyses in an American family and
\end{abstract}

$\mathrm{D}^{\mathrm{s}}$ EAFNESS affects approximately one person in two by the age of 80 years. ${ }^{1}$ Hearing loss also affects about one in every thousand children. ${ }^{1,2}$ More than 60 percent of the cases of profound early-onset deafness are caused by genetic factors, in most cases probably single gene mutations. ${ }^{3}$ About 75 percent of the people with genetically determined deafness have no additional clinical abnormalities. The other 25 percent have clinically recognizable signs that constitute an identifiable syndrome. ${ }^{1-3}$ In progressive hearing loss in the later decades, environmental causes play an important part, although underlying genetic risk factors are also likely to be involved.

A number of forms of syndromic deafness have been mapped by genetic-linkage analysis. Usher's syndrome is genetically heterogeneous, involving loci on chromosomes $1 \mathrm{q}, 14 \mathrm{q}, 11 \mathrm{p}$, and $11 \mathrm{q},{ }^{4-8}$ but the respective genes have not been cloned yet. Waardenburg's syndrome, characterized by pigmentary abnormalities and sensorineural deafness, is due to

From the Departments of Medical Genetics (P.C., G.V.C., J.K.D., P.J.W.) and Otorhinolaryngology (P.V.H.), University of Antwerp, Antwerp, Belgium; the Ear, Nose, and Throat Department, Padjadjaran University Medical School, Bandung, Indonesia (B.D.); the Center for Hereditary Communication Disorders, Boys Town National Research Hospital, Boys Town, Nebr. (S.D.S., W.J.K.); the Department of Human Genetics, Medical Genetics Center, Leiden University, Leiden, the Netherlands (R.R.F.); the Department of Neurology (G.W.P.), and the Ear, Nose, and Throat Department (C.W.R.J.C.), Academic Hospital Nijmegen, Nijmegen, the Netherlands; the Ear, Nose, and Throat Department, Academic Hospital Utrecht, Utrecht, the Netherlands (E.H.H.); and the Department of Clinical Genetics, Erasmus University, Rotterdam, the Netherlands (B.A.O.). Address reprint requests to Dr. Van Camp at the Department of Medical Genetics, University of Antwerp-UIA, Universiteitsplein 1, 2610 Antwerp, Belgium.

Supported by a grant (to Drs. Willems and Van Camp) from the University of Antwerp, a grant (to Dr. Van Camp) from the Nationaal Fonds voor Wetenschappelijk Onderzoek, a grant (to Drs. Van de Heyning and Djoyodiharjo) from the Vlaamse Interuniversitaire Raad, and a grant (P60-DC-00982, to Dr. Smith) from the National Institute on Deafness and Other Communication Disorders. Dr. Van Camp holds a postdoctoral research position with the Nationaal Fonds voor Wetenschappelijk Onderzoek. a Dutch family with similar patterns of hereditary hearing loss.

Results. In the extended Indonesian family, a gene linked to deafness mapped to chromosome $1 p$, with a multipoint lod score of more than 7. In the American family, deafness was linked to the same locus on chromosome $1 p$, with a multipoint lod score of more than 5 . In the Dutch family, however, this locus was ruled out. The flanking markers D1S255 and D1S211 defined a region of $6 \mathrm{cM}$ on chromosome $1 p$ that is likely to contain the gene associated with deafness in the first two families.

Conclusions. In some families with early-onset autosomal dominant hearing loss, the responsible gene is on chromosome 1p. (N Engl J Med 1994;331:425-31.)

mutations in the $P A X 3$ gene, a gene involved in embryonic development. ${ }^{9,10}$ In Alport's syndrome, there is a combination of progressive loss of kidney function and progressive sensorineural hearing loss, caused by mutations in the collagen $\alpha 5$ (IV) gene. Syndromic deafness is usually the consequence of maldevelopment of specific organs or structures, and the genes responsible for them are generally structural proteins or genes involved in development.

Little is known about the genes involved in human nonsyndromic genetic deafness. Localization of these genes depends on genetic-linkage analysis of large families. In many cases the most efficient strategy is a genome search, in which typing of genetic markers over the whole genome is carried out in large families with many affected members, to identify cosegregation with the disease. However, because marriages between deaf people are frequent in the Western world, affected families may often have more than one gene for deafness as well as hearing loss due to nongenetic factors. Consequently, large pedigrees with a clear pattern of segregation of only one factor responsible for hearing loss are uncommon. Studying many small families cannot overcome this problem because the genes responsible for hearing loss may differ from family to family.

One way to overcome these problems is to study families from relatively isolated populations. This strategy proved to be successful in a large Costa Rican family with autosomal dominant nonsyndromic hearing loss that first affected the low frequencies, ${ }^{11}$ in which the genetic defect was mapped to the long arm of chromosome $5,{ }^{12}$ and in a Tunisian family with a recessive form of nonsyndromic deafness linked to chromosome 13q. ${ }^{13}$ Only a few additional genes encoding for nonsyndromic deafness have been located, including two encoding for X-linked forms of heredi- 
tary deafness, one ${ }^{14}$ of which has been linked to chromosome Xq12 and the other ${ }^{15}$ to chromosome Xq21.1. None of these genes have been isolated yet. Also, a mutation in the mitochondrial $12 \mathrm{~S}$ ribosomal RNA has been described in white families with maternally transmitted susceptibility to aminoglycoside ototoxicity and in an Israeli-Arab family with mitochondrial inheritance of hearing loss. ${ }^{16}$

In this study we performed a genome search to localize a gene for nonsyndromic deafness in a large Indonesian family with nonsyndromic, autosomal dominant progressive sensorineural hearing loss first affecting the high frequencies.

\section{Methods}

\section{Patients}

We performed pure-tone audiometry with aerial conduction at $250,500,1000,2000,4000,6000$, and $8000 \mathrm{~Hz}$ and with bone conduction at $500,1000,2000$, and $4000 \mathrm{~Hz}$. Family members were considered to be affected only if they had bilateral sensorineural hearing loss of more than $25 \mathrm{~dB}$ at more than one frequency or of more than $30 \mathrm{~dB}$ at one frequency (with respect to the age-dependent curve of the general population ${ }^{17}$ ). Members 30 years old or older whose audiograms were normal according to the age-dependent control curve ${ }^{17}$ were considered to be unaffected. Members at risk who were less than 30 years old and whose audiograms were normal were not included in the linkage analysis. Patients with sensorineural hearing loss suspected of being due to other factors, such as infection, chronic middle-ear disease, otologic trauma or ototoxic antibiotics, and Meniere's disease, were excluded from the linkage analysis.

\section{DNA Analysis}

Genomic DNA was extracted by a standard technique. ${ }^{18}$ Microsatellite polymorphisms were amplified by polymerase chain reaction and analyzed on polyacrylamide gels, as described by Hughes. ${ }^{19}$

\section{Linkage Analysis}

Linkage analysis was performed with the software package Linkage (version 5.1). ${ }^{20}$ An estimated gene frequency of $2.5 \times 10^{-5}$ for nonsyndromic autosomal dominant deafness affecting the high frequencies was used in the calculations, and penetrance was set at 100 percent because no evidence of nonpenetrance was found in the three families studied. Allele frequencies were set equal to each other for the markers used in the genome search. After linkage had been detected, Indonesian allele frequencies for the Généthon markers that were subsequently used were calculated on the basis of the genotypes of 42 unrelated healthy Indonesians. In the white families from the United States and the Netherlands, the allele frequencies for whites in the Genome Database ${ }^{21}$ were used.

\section{Results}

\section{Patients}

\section{Indonesian Family}

A high concentration of cases of deafness with a strong familial character was known to exist in an isolated village, Mekarsari, with a total population of approximately 4000, located south of Bandung, the capital of West Java. An anamnestic pedigree was reconstructed for 821 family members, of whom 140 were deaf; these affected members were descended from a common ancestor who had lived seven generations ago in West Java. The pattern of deafness in this family clearly showed an autosomal dominant inheritance with high penetrance, given the several affected generations, the absence of transmission of deafness by members with normal hearing, the ratio of members with deafness to siblings with normal hearing, the sex ratio, and the transmission of deafness by affected males. Family members described hearing loss that was first noticed in the second or third decade of life and that was preceded by tinnitus in most cases. In general, the hearing loss increased in less than 10 years to more than $60 \mathrm{~dB}$ (Fletcher index), resulting in an inability to understand speech. Clinical and otoscopic examinations, pure-tone audiometry, tympanometry, and acoustic-reflex testing were conducted in 392 family members. All affected members had hearing losses of at least $30 \mathrm{~dB}$ by the age of 30 years and of at least $55 \mathrm{~dB}$ by the age of 40 . More than 30 children under the age of 10 years who had affected parents were tested by audiometry, but no hearing loss was detected, indicating that hearing loss in this family starts in general after the age of 10 . Affected members typically had bilateral, symmetric sensorineural hearing loss and normal tympanograms. The audiograms varied markedly, ranging from curves showing a normal threshold up to $2000 \mathrm{~Hz}$ but a dip at $6000 \mathrm{~Hz}$ or a very steep drop at higher frequencies, to relatively flat curves showing severe hearing loss at all frequencies. In patients with mild or moderate hearing loss, acoustic reflexes could be detected at levels less than $60 \mathrm{~dB}$ above the pure-tone threshold, demonstrating recruitment. Fifteen patients with deafness underwent complete diagnostic evaluations: their phenotypes were normal except for their hearing loss, and extensive ophthalmologic and neurologic examination detected no abnormality in any of them. All 15 patients had normal results on a number of hematologic tests as well as tests of thyroid, kidney, and liver function.

\section{American Family}

An American family had 27 members with autosomal dominant sensorineural hearing loss over four generations. The family was of European descent and traced its ancestors to France and Luxembourg. All family members included in this study were tested audiometrically. There was no indication of nonpenetrance of the hearing loss. A hearing loss of at least 60 $\mathrm{dB}$ was diagnosed in several of the affected members by the age of six years. Every patient had hearing loss of at least $55 \mathrm{~dB}$ by the age of 30 , and most had profound hearing loss by the age of 40 . All patients had audiograms on which a sloping configuration beginning after the $1000-\mathrm{Hz}$ mark was maintained, although family members with severe-to-profound hearing loss in the high frequencies also had moderate loss in the low and middle frequencies. Tinnitus was re- 
ported by some of the affected members, but no other consistent medical or physical abnormalities were detected.

\section{Dutch Family}

In a Dutch family comprising 338 members in five generations, 66 members were found to have autosomal dominant, progressive sensorineural hearing loss first involving the high frequencies. This family has been described previously. ${ }^{22-26}$ Hearing loss started between the ages of 5 and 15 years, affecting the high frequencies. With increasing age the low frequencies also became affected, and in the fifth decade the hearing loss became severe. Vestibular functions were not affected, and no family member reported tinnitus. There were no associated abnormalities in this family, indicating that the deafness was nonsyndromic.

\section{Linkage Analysis \\ Indonesian Family}

We first tested the Indonesian family for linkage with the known loci ${ }^{12,13}$ for hereditary deafness on chromosome $5 q$ and $13 q$, but linkage to both chromosomal regions was excluded by multipoint linkage analysis. Since no loci other than the $5 \mathrm{q}$ and $13 \mathrm{q}$ loci are known to cause nonsyndromic deafness, a search of the complete genome was subsequently initiated. The Indonesian family was coded as three separate families in the linkage programs, because of the uncertainty of some family relationships (Fig. 1, dashed line), although this resulted in some loss of power in the linkage analysis. Since no allele frequencies are known for the Indonesian population, allele frequencies equal to each other were used in the linkage calculations, eliminating the need for typing of a large number of unrelated Indonesians for all the markers used in the genome search. Although the use of incorrect allele frequencies may lead to false positive evidence of linkage under certain conditions, the power to detect a true linkage remains largely unaffected. ${ }^{27-29}$ After 60 microsatellite markers randomly distributed over the genome had been typed, producing negative or inconclusive results, linkage was detected with the marker DlS186, located on chromosome $1 \mathrm{p}$. This marker gave a maximal lod score of 8.39 at 0 percent recombination with the gene for deafness.

In view of the detailed Généthon genetic maps, ${ }^{30}$ which can be correlated with extensive physical maps, we analyzed a number of markers from the Généthon microsatellite genetic map covering the same chromosomal region (Fig. 2). Because the marker D1S186 cannot be positioned on this map, it was not used further. Analysis with the markers D1S255 and D1S193 produced lod scores of 7.06 and 2.14, both at 0 percent recombination. The results of this analysis are shown in Table 1. Varying the gene frequency between $10^{-3}$ and $10^{-6}$, as well as changing the pene- trance to 95 percent, had only minor effects on the lod scores and did not alter the conclusions. Multipoint linkage analysis with D1S255 and D1S193 revealed a peak lod score of 7.70. Haplotypes were constructed with the four markers D1S201, D1S255, D1S193, and D1S211, revealing interesting recombinational events (Fig. 2). Obligate recombinations between D1S201 and the gene for deafness were found in two affected members (Fig. 1, members V-9 and VI-2). These obligate recombinations were confirmed by the finding that allele 2 segregated with deafness in all offspring of members II- 1 and II-2, whereas allele 7 segregated with hearing loss in the offspring of member II-4, implying an inferred recombination in at least one common ancestor of all these members. An obligate recombination between the gene for deafness and the marker D1S211 was found in member V-10 (Fig. 1). All these recombinational events localized the gene for deafness between D1S201 and D1S211 in an interval of approximately $11 \mathrm{cM}$.

\section{American Family}

Multipoint linkage analysis with chromosome 5 markers excluded the possibility that chromosome $5 q$ was the locus of the gene for deafness ${ }^{12}$ in the American family. To test this family for linkage with the chromosome lp locus, typing for D1S201, D1S255, D1S193, and D1S211 was carried out (Fig. 1). The highest lod scores, 4.97 and 4.77, were obtained with DIS193 and D1S211, respectively, both at 0 percent recombination (Table 1). Multipoint linkage analysis with D1S255 and D1S193 yielded a peak lod score of 5.89. To locate the recombinants in this family, haplotypes were constructed with these four markers (Fig. 1). A recombination between D1S255 and the gene for deafness was found in member IV -5 , who was healthy and had a normal audiogram at the age of 40 years (Fig. 1). The finding of this recombination localized the gene for deafness centromeric to DIS255 in this family (Fig. 2).

\section{Dutch Family}

The chromosome 5 locus $^{12}$ was ruled out in the Dutch family by multipoint linkage analysis. Family members were subsequently tested for linkage with the chromosome lp locus by means of Généthon markers D1S255 and D1S193 (Fig. 2 and Table 1). Negative lod scores were obtained with both markers (Table 1). Multipoint linkage analysis with D1S255 and D1S193 produced lod scores below -2 for a region ranging from more than $10 \mathrm{cM}$ telomeric from DIS255 to more than $10 \mathrm{cM}$ centromeric from DIS193, thus excluding the entire candidate region on chromosome $1 \mathrm{p}$.

\section{Discussion}

In this study of an extended Indonesian family with autosomal dominant deafness affecting high frequen- 
A

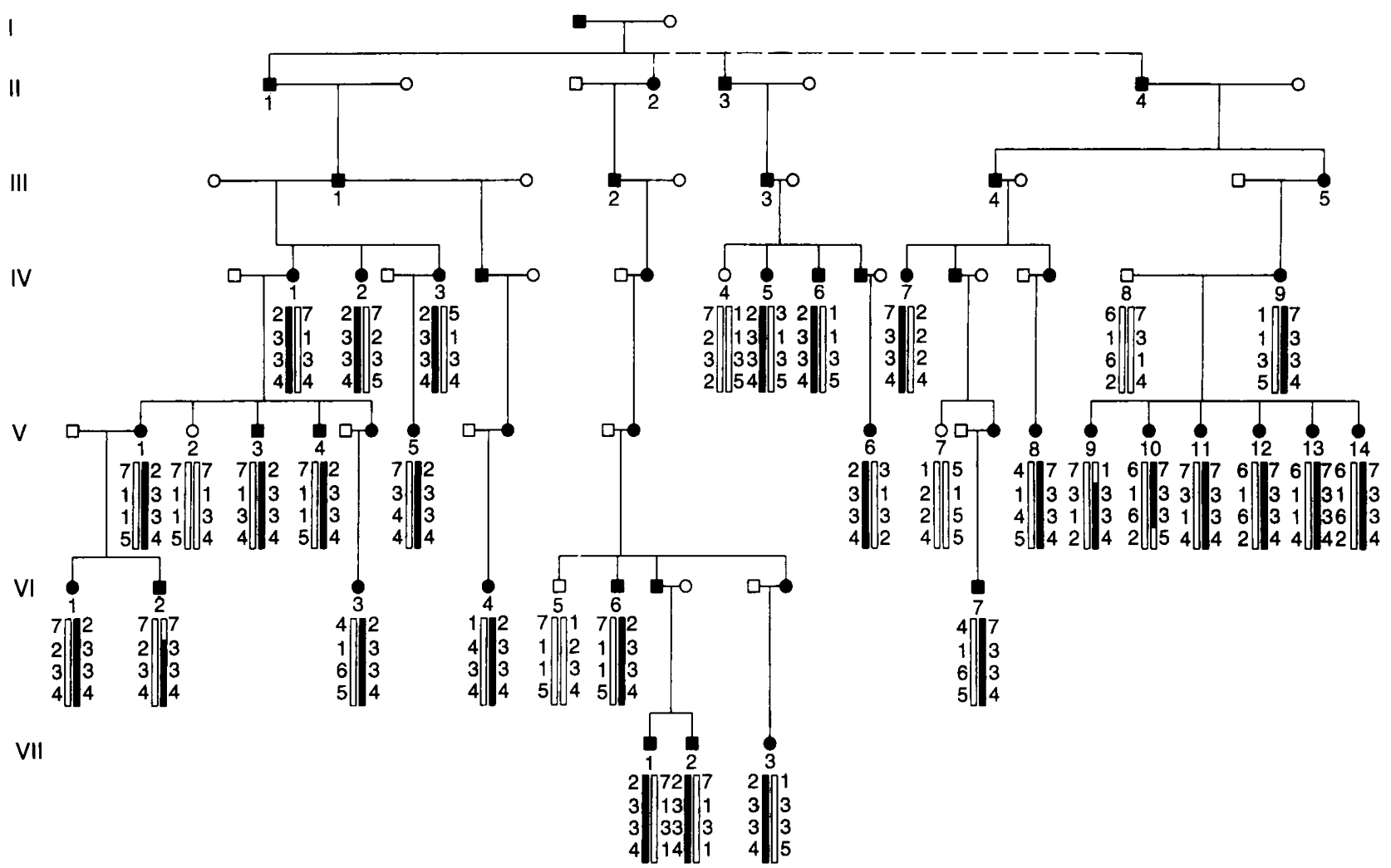

B

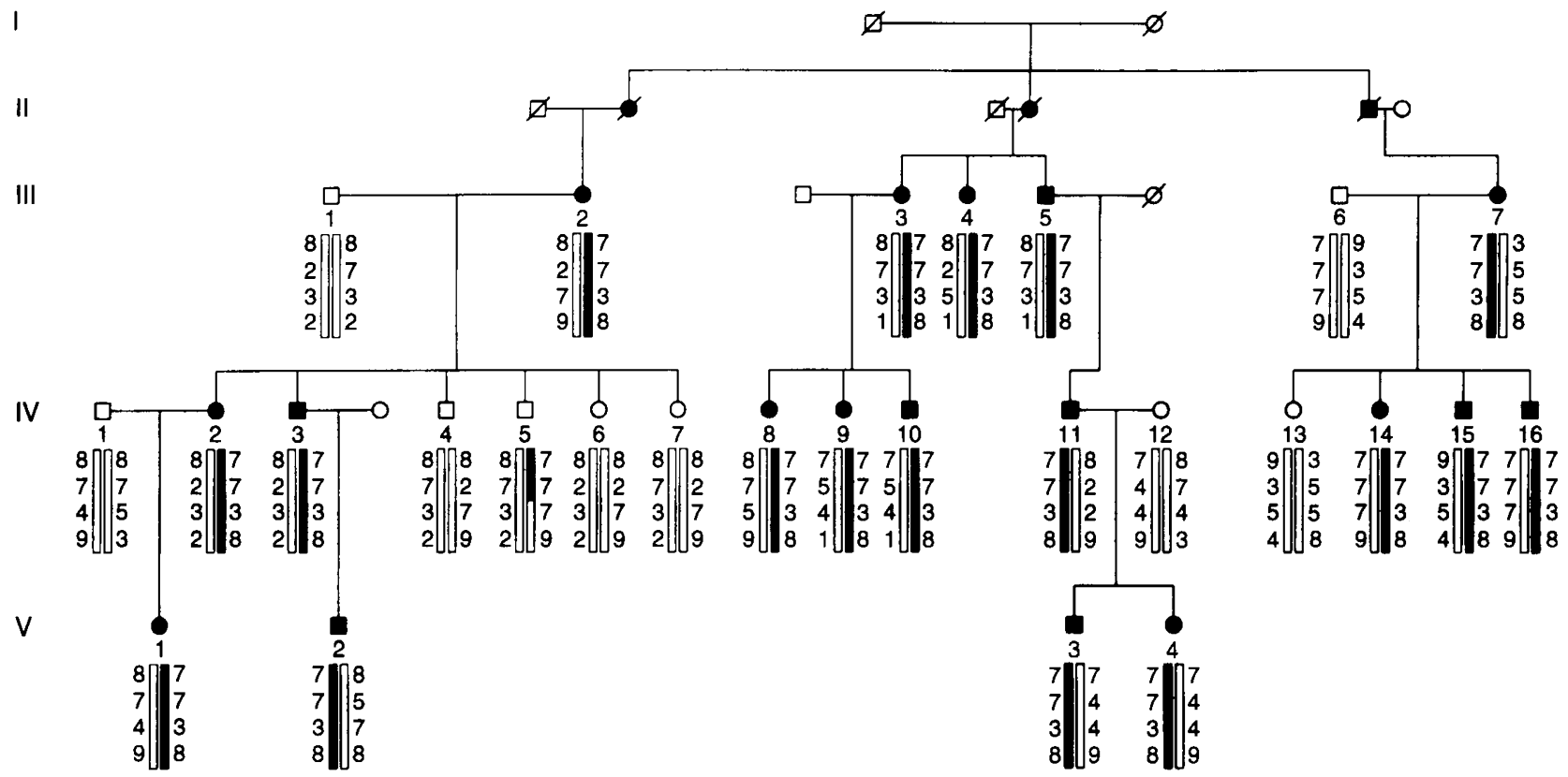


C

Dutch Family

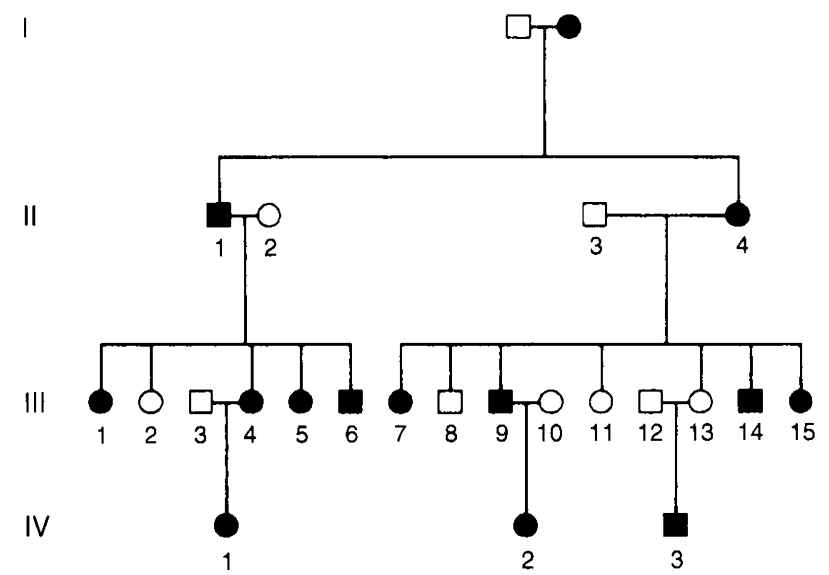

cies, we localized the gene for deafness to chromosome $\mathrm{lp}$ after searching the genome with microsatellite markers dispersed over the whole genome. This localization was helped by two factors: the family lived in two isolated small villages close to each other, thereby facilitating the construction of a large pedigree; and selective mating in this population is infrequent because of the social acceptance of deafness by the community and the rather late onset of deafness in family members, limiting the introduction of genes for secondary deafness.

After detecting linkage with chromosome $1 p$ in the Indonesian family, we performed linkage analysis in two white families with autosomal dominant deafness affecting the high frequencies. Linkage to the chromosome $1 \mathrm{p}$ region was also found in the American family. Although deafness in this family was linked to the same locus as in the Indonesian family, it developed at an earlier age. Whereas hearing loss could never be detected in members of the Indonesian family before the age of 10 , it was diagnosed in several children in the American family by the age of 6 . This could be due to the presence of different mutations with different expression in the two families. Since the Indonesian and the American families are of different ethnic backgrounds, it is likely that the gene responsible for deafness on chromosome $\mathrm{lp}$ is responsible for hearing loss in other families throughout the world. Therefore, we are currently performing linkage analysis in more families with autosomal dominant hearing loss.

Autosomal dominant hearing loss of high tones is genetically heterogeneous. We found one locus on chromosome lp responsible for hearing loss in the Indonesian and American families, and determined that there must be another, unknown locus in the Dutch family. Furthermore, there is at least one locus for low-frequency hearing loss on chromosome $5 .^{12}$ Autosomal recessive nonsyndromic deafness is also genetically heterogeneous, since linkage to the locus on chromosome 13q has not been demonstrated in all
Figure 1. Part of the Pedigree of an Indonesian Family, an American Family, and a Dutch Family with Autosomal Dominant Deafness.

Only family members whose DNA was studied or who are necessary to reconstruct the pedigrees are represented. Affected family members are represented by solid symbols, male family members by squares, and female members by circles. The apparent excess of affected members represents an ascertainment bias, since more affected than unaffected members cooperated in this study and members less than 30 years old with normal audiograms were excluded from the pedigrees. The most likely haplotype for the chromosome 1 markers is shown below each member of the Indonesian and American families from whom DNA was available; each number beside a bar is an allele number. The solid portion of the bars indicates the haplotypes linked to the gene for deafness in each branch of the pedigree. The order of the markers from the top to the bottom of each bar is D1S201, D1S255, D1S193, and D1S211. In the American family, it is not known which of the parents in generation I was affected.

families affected. ${ }^{13}$ Other loci for nonsyndromic deafness will no doubt be identified as genome searches are carried out in more families.

In the Indonesian family, the gene for deafness was located with a high degree of certainty in an interval of $11 \mathrm{cM}$ between D1S201 and D1S211, because sev-

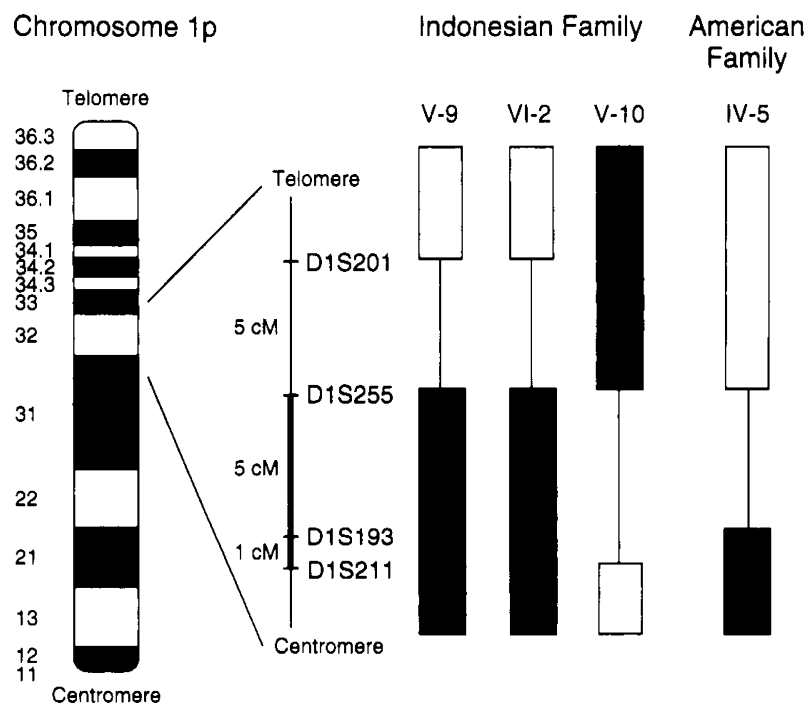

Figure 2. Key Recombinants between the Gene for Hearing Loss and Genetic Markers in the Indonesian and American Families, in Relation to a Microsatellite Genetic Map of Chromosome 1p.

The microsatellite map was obtained from the Genethon data base. ${ }^{30}$ The bars indicate chromosomal regions that contain the gene for deafness, vertical lines noninformative regions, and open bars regions that do not include the gene. In Indonesian family members V-9 and V1-2, recombination has occurred between the gene for deafness and marker D1S201, localizing the gene centromeric to D1S201. The recombination between D1S211 and the gene in family member V-10 localizes the gene telomeric to D1S211. In the American family, there is a recombination in unaffected family member IV -5 between the gene for deafness and D1S255, localizing the gene centromeric to D1S255. Combining the information from all the recombinations delineates the candidate region between the markers D1S255 and D1S211. 
Table 1. Two-Point Lod Scores for the Association of Hearing Loss with Chromosome 1p Loci in Three Families with Autosomal Dominant Hearing Loss.*

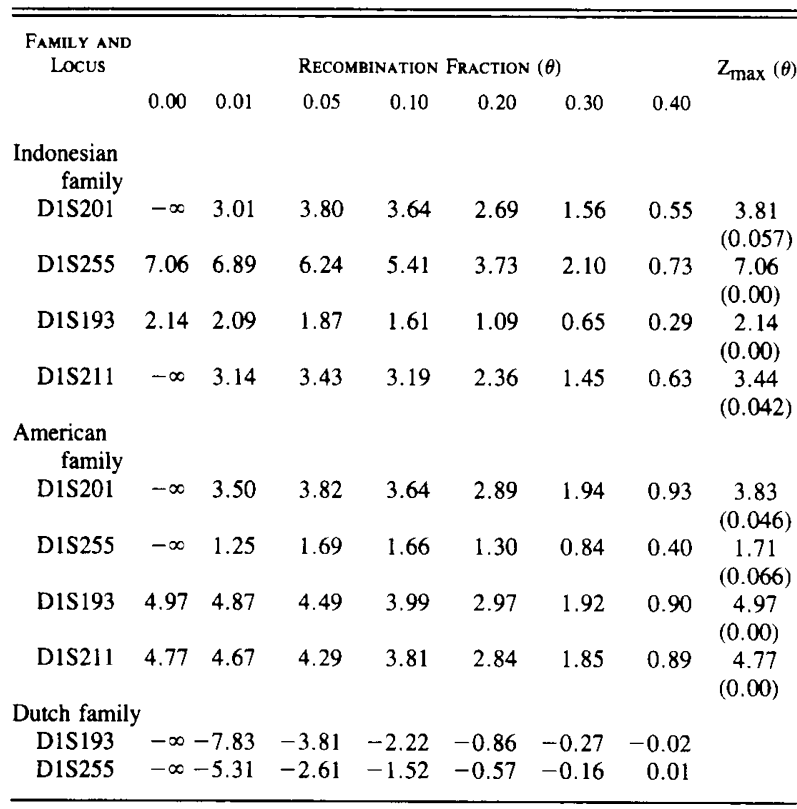

* $\theta$ denotes the frequency of recombination, and $\mathrm{Z}_{\max }$ the maximal lod score.

eral recombinational events were found in affected members (Fig. 1 and 2). In the American family, a recombination between D1S255 and the gene for deafness in an apparently unaffected member localized the gene centromeric to D1S255 (Fig. 1 and 2). When the member with the recombination was examined at the age of 40 , he had no signs of hearing loss; it is therefore likely that he did not inherit the gene for deafness, since every affected family member more than 30 years old had a hearing loss of more than 55 $\mathrm{dB}$. When the findings in this family are combined with those in the Indonesian family, it can be seen that the genetic defect causing the hearing loss in these two families is most probably located in an interval of $6 \mathrm{cM}$ between D1S255 and D1S211 on the short arm of chromosome 1 (Fig. 2).

A number of genes may be located in this region, although the exact place of most of them on the genetic map is unknown. The candidate genes include several collagen genes: $\alpha 2$ (VIII), ${ }^{31} \alpha 2$ (IX) ${ }^{32}$ and $\alpha 1$ $(\mathrm{XVI}){ }^{33,34}$ These collagen genes are of particular interest because mutations in the collagen $\alpha 5$ (IV) gene can lead to syndromic deafness. ${ }^{35}$

The genes responsible for nonsyndromic deafness are likely to have specific roles in the hearing process. However, little is known at the molecular level about the process of hearing in the cochlea, and virtually nothing is known about the genes involved. The identification of these genes will be a first step in the elucidation of the physiologic mechanisms of hearing and could lead to substantial improvements in our ability to diagnose and possibly even treat deafness.
We are indebted to the Health Research Unit and the Departments of Anthropology, Neurology, and Ophthalmology of the Padjadjaran University of Bandung, Indonesia, for help in construction of the pedigree and clinical examination of the patients; to L. Sandkuyl and P. Heutink for help with the linkage programs; to C. Connolly for statistical analysis; and to J. Kenyon, A. Brower, and D. Hoover for technical assistance.

\section{REFERENCES}

1. Morton NE. Genetic epidemiology of hearing impairment. Ann N Y Acad Sci 1991;630:16-31

2. Reardon W. Genetic deafness. J Med Genet 1992;29:521-6

3. Marazita ML, Ploughman LM, Rawlings B, Remington E, Arnos KS, Nance WE. Genetic epidemiological studies of early-onset deafness in the U.S. school-age population. Am J Med Genet 1993;46:486-91.

4. Kimberling WJ, Weston MD, Moller C, et al. Localization of Usher syndrome type II to chromosome lq. Genomics 1990;7:245-9.

5. Lewis RA, Otterud B, Stauffer D, Lalouel JM, Leppert M. Mapping recessive ophthalmic diseases: linkage of the locus for Usher syndrome type II to a DNA marker on chromosome 1q. Genomics 1990;7:250-6.

6. Kaplan J, Gerber S, Bonneau D, et al. A gene for Usher syndrome type I (USH1A) maps to chromosome 14q. Genomics 1992;14:979-87.

7. Kimberling WJ, Moller CG, Davenport S, et al. Linkage of Usher syndrome type I gene (USHIB) to the long arm of chromosome 11. Genomics 1992;14:988-94.

8. Smith RJH, Lee EC, Kimberling WJ, et al. Localization of two genes for Usher syndrome type I to chromosome 11. Genomics 1992;14:995-1002.

9. Tassabehji M, Read AP, Newton VE, et al. Waardenburg's syndrome patients have mutations in the human homologue of the Pax-3 paired box gene. Nature 1992;355:635-6.

10. Hageman MJ, Delleman JW. Heterogeneity in Waardenburg syndrome. Am J Hum Genet 1977;29:468-85.

11. Léon PE, Bonilla JA, Sanchez JR, et al. Low frequency hereditary deafness in man with childhood onset. Am J Hum Genet 1981;33:209-14.

12. Léon PE, Raventos H, Lynch E, Morrow J, King M-C. The gene for an inherited form of deafness maps to chromosome 5q31. Proc Natl Acad Sci U S A 1992;89:5181-4

13. Guilford P, Ben Arab S, Blanchard S, et al. A non-syndrome form of neurosensory, recessive deafness maps to the pericentromeric region of chromosome 13q. Nat Genet 1994;6:24-8.

14. Robinson D, Lamont M, Curtis G, Shields DC, Phelps P. A family with Xlinked deafness showing linkage to the proximal $\mathrm{Xq}$ region of the $\mathrm{X}$ chromosome. Hum Genet 1992;90:316-8.

15. Bach 1 , Brunner $H G$, Beighton $P$, et al. Microdeletions in patients with gusher-associated, X-linked mixed deafness (DFN3). Am J Hum Genet 1992;51:38-44.

16. Prezant TR, Agapian JV, Bohlman MC, et al. Mitochondrial ribosomal RNA mutation associated with both antibiotic-induced and non-syndromic deafness. Nat Genet 1993;4:289-94.

17. Hull RH. Hearing evaluation of the elderly. In: Katz J, ed. Handbook of clinical audiology. 2nd ed. Baltimore: Williams \& Wilkins, 1978:426-41.

18. Miller SA, Dykes DD, Polesky HF. A simple salting out procedure for extracting DNA from human nucleated cells. Nucleic Acids Res 1988;16: 1215.

19. Hughes AE. Optimization of microsatellite analysis for genetic mapping. Genomics 1993;15:433-4.

20. Lathrop GM, Lalouel JM. Easy calculations of lod scores and genetic risks on small computers. Am J Hum Genet 1984;36:460-5.

21. Cuticchia AJ, Fasman KH, Kingsbury DT, Robbins RJ, Pearson PL. The GDB human genome data base anno 1993. Nucleic Acids Res 1993;21: 3003-6.

22. Huizing EH, van Bolhuis AH, Odenthal DW. Studies on progressive hereditary perceptive deafness in a family of 335 members. II. Characteristic pattern of hearing deterioration. Acta Otolaryngol (Stockh) 1966;61:161-7.

23. Idem. Studies on progressive hereditary perceptive deafness in a family of 335 members. I. Genetical and general audiological results. Acta Otolaryngol (Stockh) 1966;61:35-41

24. Huizing EH, van den Wijngaart WSIM, Verschuure J. A follow-up study in a family with dominant progressive inner ear deafness. Acta Otolaryngol (Stockh) 1983;95:620-6.

25. van den Wijngaart WSIM, Verschuure J, Brocaar MP, Huizing EH. Followup study in a family with dominant progressive hereditary sensorineural hearing impairment. I. Analysis of hearing deterioration. Audiology 1985; 24:233-40.

26. van den Wijngaart WSIM, Huizing EH, Niermeijer MF, Verschuure J, Brocaar MP, Blom W. Follow-up study in a family with dominant progressive hereditary sensorineural hearing impairment. II. Clinical aspects. Audiology 1985;24:336-42. 
27. Ott J. Strategies for characterizing highly polymorphic markers in human gene mapping. Am J Hum Genet 1992;51:283-90.

28. Knowles JA, Vieland VJ. Gilliam TC. Perils of gene mapping with microsatellite markers. Am J Hum Genet 1992:51:905-9.

29. Freimer NB, Sandkuijl LA, Blower SM. Incorrect specification of marker allele frequencies: effects on linkage analysis. Am J Hum Genet 1993:52 $1102-10$

30. Weissenbach J, Gyapay G, Dib C, et al. A second-generation linkage map of the human genome. Nature 1992;359:794-801.

31. Muragaki Y, Jacenko O, Apte S, Mattei M-G, Ninomiva Y. Olsen BR. The $\alpha 2$ (VIII) collagen gene: a novel member of the short chain collagen family located on the human chromosome 1. J Biol Chem 1991;266:7721-7.
32. Perälä M, Hänninen M, Hästbacka J, Elima K, Vuorio E. Molecular cloning of the human $\alpha 2$ (IX) collagen cDNA and assignment of the human COL9A2 gene to chromosome 1. FEBS Lett 1993:319:177-80

33. Pan T-C, Zhang R-Z, Mattei M-G, Timpl R, Chu M-L. Cloning and chromosomal location of human $\alpha$ l(XVI) collagen. Proc Natl Acad Sci U S A 1992:89:6565-9.

34. Yamaguchi N, Kimura S, McBride OW, et al. Molecular cloning and partial characterization of a novel collagen chain, $\alpha 1(\mathrm{XVI})$, consisting of repetitive collagenous domains and cysteine-containing non-collagenous segments. J Biochem (Tokyo) 1992:112:856-63

35. Barker DF, Hostikka SL, Zhou J, et al. Identification of mutations in the COL4A5 collagen gene in Alport syndrome. Science 1990;248:1224-7.

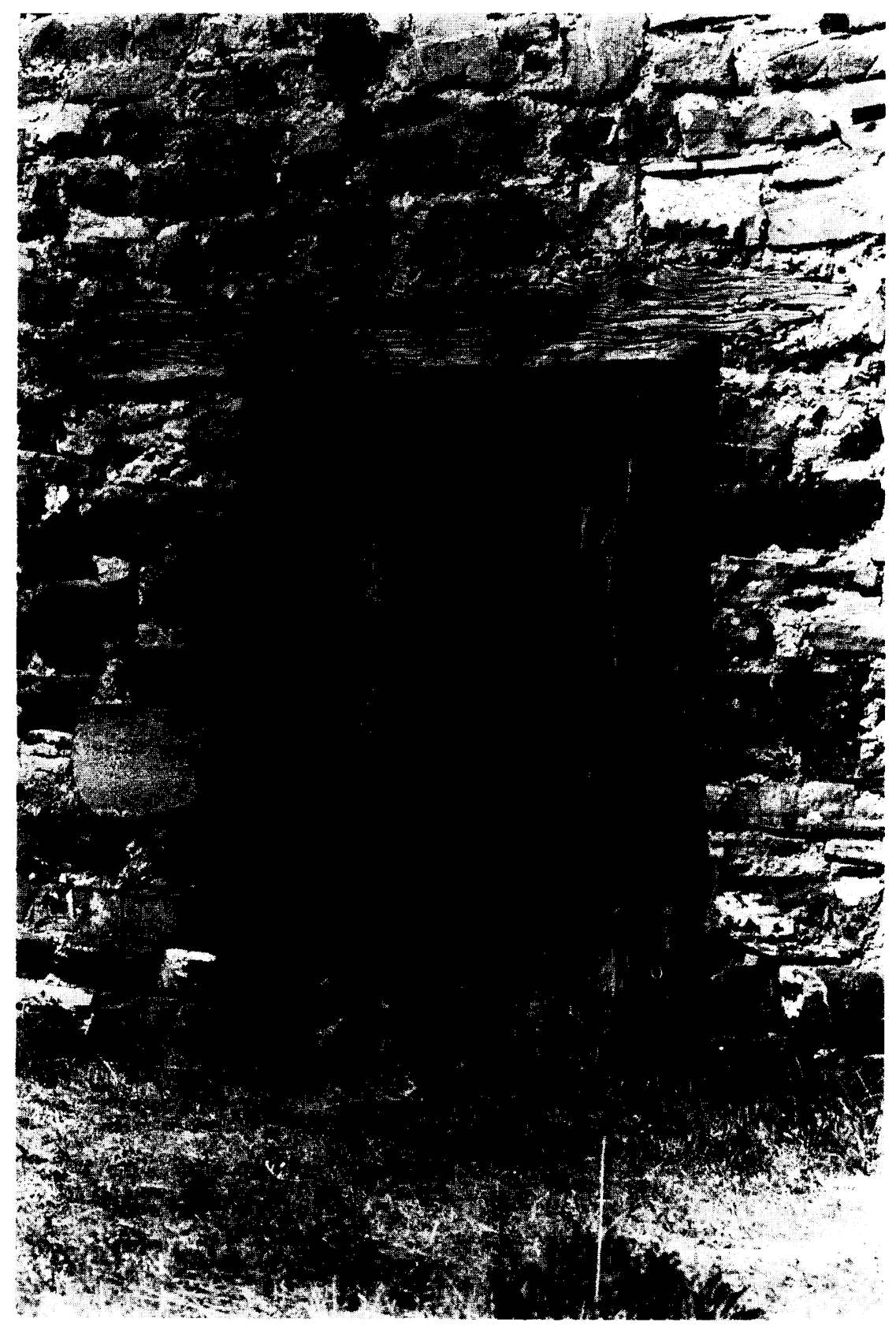

Ancient Door

José Berciano, M.D. 